\title{
Finger Printing of the Anatomical Markers, HPTLC Profile and Heavy Metals Content in the Leaves of Aristolochia indica Linn.
}

\author{
Madathilparambil Vasu Sudhakaran \\ UGC-Academic Staff College, University of Calicut, Calicut University PO, Malappuram District, Kerala, INDIA.
}

\begin{abstract}
Background: Aristolochia indica Linn is now an endangered medicinal plant belonging to the family Aristolochiaceae. Many ethono-botanically important species of Aristolochia were found used in the traditional forms of medicine for the treatment of various illnesses. Aim: The present study concerns the microscopic, fluorescent, powder, quantitative microscopic characteristics of the leaves of Aristolichia indica Linn and its physico-chemical standards. Materials and Methods: Morpho-histological profile, Highperformance thin-layer chromatographic (HPTLC) finger print profile, and heavy metals content of the leaves of Aristolichia indica Linn. Results: The presence of camptodromous pinnate venation with pentagonal shaped areoles with linear veinlet endings, non-glandular hooked trichomes, amphistomatic and anomocytic stomata, small palisade ratio, small stomatal index were the anatomical features characteristics of the taxon. Physico-chemical evaluation of the leaves gave moisture content of $10.5 \%$, total ash $12.7 \%$, acid insoluble ash $1.9 \%$, acid soluble ash $10.8 \%$. Highperformance thin-layer chromatographic (HPTLC) identification of marker compound (Aristolochic acid I or (AAI)) in methanol extract of leaves was carried out. The developed HPTLC Chromatogram had revealed nine phytoconstutents in extract of leaf sample. The Rf value for Aristolochic acid $\mathrm{I}\left(\mathrm{C}_{17} \mathrm{H}_{11} \mathrm{NO}_{7}\right)$ was found to be 0.41 and densitometric scanning had shown $\lambda_{\text {max }}$ at $318 \mathrm{~nm}$ for the marker compound. The content of marker constituent (AA I) present in shade-dried leaves of Aristochia indica Linn was estimated
\end{abstract}

as $0.049 \%$. The Flame atomic absorption spectrometric determination of elements had shown appreciable amounts of the elements such as $\mathrm{Fe}(0.5442 \mathrm{mg} / \mathrm{g}), \mathrm{Zn}(0.026 .82 \mathrm{mg} / \mathrm{g}), \mathrm{Ni}(0.008 \mathrm{mg} / \mathrm{g}$, ) and $\mathrm{Cu}(0.002 \mathrm{mg} / \mathrm{g})$ by dry weight of the leaves of Aristolichia indica. Conclusion: The present study suggests that the delineated characteristics of the leaves of $A$. indica, could tag as the identifying parameters to substantiate and authenticate the raw drugs from the spurious/adulterants materials and could also be effectively used for the regulatory perspectives and quality assessment of Aristololic acid I in the medicinal formulation/finished products. The presence of important mineral elements inside this plant showed that it could be a nutritious plant and important to the human health.

Key words : Aristolic acid, Physico-chemical parameters, Stomatal index, Areoles, HPTLC finger print, Heavy metals.

Correspondence:

Dr. Madathilparambil Vasu Sudhakaran, Associate Professor, UGCAcademic Staff College, University of Calicut, Calicut University PO, Malappuram District, Kerala, INDIA.

Phone no: 91+9447500125

E-mail: dr.sudhakaranvasu@gmail.com

DOI: $10.5530 /$ pj.2016.2.4

\section{INTRODUCTION}

The use of botanical and other natural products as traditional medicine and dietary supplements is increasingly popular owing to the perception that they are safer than prescription drugs. The long-history of use in traditional systems of medicine at the expense of using human body as the experimental screening model, accorded herbals the reputation of being looked upon as the gentle form of medicine, devoid of conspicuous side effects. Aristolochia indica Linn is now an endangered medicinal plant belongs to the family Aristolochiaceae. Aristolochia is an important genus both numerically (consisted of about 500 species) as well as medicinally. The genus has attracted great interest among investigators because of their multiple uses in traditional forms of medicine, and various bioactivity reports on its crude extracts. According to Kuo et al. ${ }^{1}$ Aristolochic acid I (AAI) is the most potent fraction of Aristolochia's constituents, and the members of this genus have been used for medicinal purposes since the Graeco-Roman period ${ }^{1}$. The name Aristolochia (Greek cristos $=$ noblest + locheia $=$ childbirth) is believed to have originated from the ancient Greek, which means "the best delivery or birth"; itself guarantors the centuries of its use in obstetrics. In Asian traditional medicine, many species of Aristolochia were found used as oxytocic agent to aid in child birth, menstrual cramps, and prevent infections in women after childbirth. ${ }^{2-3}$ It is also found used as medicaments for the treatment of edema, arthritis, gout, rheumatism, as analgesic, anti-inflammatory, diuretic agents and tonics ${ }^{4-5}$ in the traditional Chinese medicine. ${ }^{6-7}$ Various Aristolochia species in the form of crude drugs as the anodynes, antiphlogistics, and detoxicants were reported to have been used in China ${ }^{8}$ and the mature fruits of A. debilis Sieb et al. Zucc for the treatment of snakebite, tuberculosis and as antihypertensive agents. ${ }^{9}$ The rhizomes of $A$. brevipes Benth were found used against snakebites, arthritis, and diarrhea by the local Tarasc people in Mexico. ${ }^{10}$ A. albida Duch a native West African species was found used for the ailment of skin diseases, dysentery, gastrointestinal colic's, and snakebites. ${ }^{11}$ In Indian System of medicine, the root and leaves of Aristolochiaspecies werefoundusedinthetreatmentforsnakebite, scorpion stings, diarrhea, inflammation and abortifacient ${ }^{9,12-13}$ and to alleviate insomnia, ease bowel obstruction, relieve symptoms of edema, cures Syphilis, Gonorrhea, and in the treatment for microbial infections. ${ }^{14}$ However, some of the contemporary Aristolochia-containing Chinese herbal preparations, mostly used for weight loss in women were reported to have found nephrotoxic and carcinogenic effects. ${ }^{15}$ Following which the use of Aristolochia-containing Chinese herbal preparations is the subject of warnings from the international regulatory agencies. ${ }^{16}$

Since Aristolochia indica Linn is an important herbal remedy in the Indian traditional medicine, and it has extensively been investigated by various workers for its phytochemical, pharmacological, Morphotaxonomical, cytological, and organogenesis and micro-propagation studies. ${ }^{17}$ However, the studies on the botanical pharmacognosy seem to be rare in literature, barring a few isolated studies on the aspects of ethono-biotanical, ${ }^{18}$ folial stomatal development, ${ }^{19}$ root morphology, ${ }^{20}$ and root anatomy. ${ }^{21-3}$ Therefore, the present study was undertaken with the objectives of delineating the anatomical markers, and develop active constituent based on High-performance thin-layer chromatographic (HPTLC) profile of the leaves of Aristolochia indica Linn. It also aims to 
analyze the physico-chemical, fluorescent, quantitative microscopy, and contents of metal elements of the leaves of Aristolochia indica Linn.

\section{MATERIALS AND METHODS}

\section{Plant Material}

Aristolochia indica Linn (Figure 1) is a perennial climber with greenish white long stem found throughout India in low hills and plains. Leaves are petiolated, glabrous and very variable, usually obovate-oblong, entire, and acuminate. Flowers are few in axillary racemes, pale-green, inflated and base narrowed into a cylindrical tube terminating in a funnel-shaped purple mouth. Capsules are oblong or globose, six chambered, seeds are ovate and winged. The dried-leaves are extremely bitter in taste.

\section{Methods}

Aristolochia indica Linn was collected from its natural habitat from the Pathanamthitta District of the State of Kerala, India. The leaves samples collected were brought to the laboratory and investigation was undertaken in the Drug Standardization Department of the Government Ayurveda College, Thiruvananthapuram, Kerala, where voucher specimens were deposited. The plant was identified and authenticated with the help of the Flora of Presidency of Madras. ${ }^{24}$ The shade-dried leaves were pulverized and passed through an 85-mesh sieve. The pulverized powder was kept in a labeled, air tight glass container. Fine hand sections of fresh leaves were taken using the razor blade and sections were stained with alcoholic Safranin (1\%), and mounted on glass slides in glycerin. Microphotographs of sections and powder analysis were made by using Olympus Microscope (Japan, Model CX 41) with CCD camera (DP2). Images were concomitantly viewed and analyzed for anatomic characteristics, and quantitative measurements were taken using Olympus Image-Pro Plus (version 5.1). The number of epidermal cells, stomatal number, stomatal index were calculated per square millimeter of leaf area from intercostals areas of fresh leaves and vein islet number and vein termination number were calculated from cleared leaves and palisade ratio was determined based on Wallis ${ }^{25}$ and size of Guard Cell Area (GCA) was estimated following Franco's formula. ${ }^{26}$ The leaves powder was cleared with absolute alcohol and mounted on glass slides for powder analysis. The descriptive terms of the anatomical features used here as per Hickey, ${ }^{27}$ Metcalfe and Chalk, ${ }^{28}$ and Sudhakaran. ${ }^{23,28-9}$ Fluorescence analysis of the leaves powder was carried out in daylight and UV light ( $254 \mathrm{~nm} \& 366 \mathrm{~nm})$ using Camang UV apparatus.

\section{Physico-chemical parameters}

An accurately weighed $3.387 \mathrm{~g}$ of shade-dried, powdered leaves were packed in a packing paper. This packed material was used for successive extraction in soxhlet apparatus for $24 \mathrm{~h}$ (approximately) with a series of solvents with increasing polarity as follows: Petroleum ether, Cyclohexane, Accetone, Ethanol and Water. Each time before extracting with the next solvent, the material was dried. After successive extractions, the extracts obtained were filtered, content were distilled, evaporated, concentrated, dried in desiccators and weighed. The respective percentage yield was calculated in $\mathrm{w} / \mathrm{w}$. The estimation of the total residual ash, acid insoluble ash, acid soluble ash, water soluble ash, and moisture content of the shade-dried powdered leaves were carried out using the standard procedure of the Ayurvedic Pharmacopeia. ${ }^{30}$

\section{Qualitative phyto-chemical analysis}

The shade-dried powdered leaves extracted with ethanol and aqueous medium were subjected to qualitative tests to identify the organic chemical constituents present in the drug.

\section{High-performance thin-layer chromatographic (HPTLC) Finger print profile}

\section{Chemicals and reagents}

Aluminum plate $(20 \times 10 \mathrm{~cm})$ pre-coated with silica gel 60 F254 (Merck) of uniform thickness was used as adsorbent. Analytically pure standard Aristolochic acid I procured from Sigma and solvents of HPLC/ Chromatographic Grade procured from Merck and Qualigens Fine Chemicals, India were used. Analytical reagent grade of concentrated acids (HCI and $\mathrm{HNO} 3$ ) were also used.

\section{Optimization of Chromatographic Conditions}

The chromatographic separation was achieved using different ratios of solvents of varying polarity and the mobile phase consisted of chloroform:methanol $(6: 2 \mathrm{v} / \mathrm{v})$ was found suitable for resolved separation of the analytes and quantification of marker compound.

\section{Standard stock solution}

The standard stock solution $0.5 \mathrm{mg} / \mathrm{mL}$ of Aristoloic acid I was prepared in HPTLC-grade methanol. One $\mathrm{ml}$ of this stock solution was diluted with $10 \mathrm{ml}$ of methanol and a working solution of $0.05 \mathrm{mg} / \mathrm{mL}$ concentration was prepared and used for the HPTLC analysis.

\section{Sample preparation}

Accurately weighed 2.028 gms of leaves powder of Aritolochia indica Linn was refluxed in $25 \mathrm{ml}$ of Methanol. Extract obtained was filtered using Whatman filter paper and transferred to a volumetric flask, and volume was made upto $50 \mathrm{ml}$ with methanol.

\section{Instrumentation}

CAMAG HPTLC System (Switzerland) equipped with CAMAG Linomat V Automatic Sample Spotter with syringe $(100 \mu \mathrm{l})$, Automatic development chamber (ADC2), UV cabinet with dual wavelength, and the densitometer consisted of TLC scanner 3 linked to WINCATS software were used for HPTLC method.

For the HPTL analyses, 4 different application volumes of the working solution were used in 4 different tracks on the pre-coated plate of Silica Gel and methanol extract of the test sample in one track (track no.12). The standard working solution and extract of leaves were applied on the plate using CAMAG LINOMAT V Applicator, the semi-automatic spotting device and Hamilton $100 \mu \mathrm{l}$ syringe. The spotting volume of standard working solution on the plate were $2,4,6$ and $8 \mu \mathrm{l}$ with a concentration ranged from 100 to $400 \mathrm{ng}$ /band respectively and $5 \mu \mathrm{l}$ for the test sample (4 Standards plus one methanol leaves sample). The plate $(20 \times 10 \mathrm{~cm})$ was developed in Automatic development chamber (ADC2), using the mobile phase chloroform: methanol $(6: 2 \mathrm{v} / \mathrm{v})$ at $26.7^{\circ} \mathrm{C}$ temperature and relative humidity 78.3. Densitometric scanning of the plate at $254 \mathrm{~nm}$ and $320 \mathrm{~nm}$ were performed using CAMAG TLC Scanner 3 , and operated by the WINCATS software. Calibration graph was plotted using the peak area vs concentration of the standard marker compound. The content of marker compound (AAI) in the methanol extract of the leaves was estimated using linear regression equation. The developed method was validated for the parameters like specificity, linearity, limit of detection (LOD) and limit of quantitation (LOQ).

\section{Flame Atomic Absorption Spectroscopic Determination of the metals}

Flame Atomic Absorption Spectroscopy was used to determine the concentration of metal elements in the powdered drug. Thermo Electron Corporation Atomic Absorption Spectrometer ( $M$ series FS 95) equipped with auto-sampler and with Deuterium background corrector was used for the metals determination. The flames used were air/acetylene. The hollow-cathode lamps for $\mathrm{Fe}, \mathrm{Zn}, \mathrm{Ni}, \mathrm{Pb}, \mathrm{Cu}$, and $\mathrm{Cd}$ were employed 
Table 1: Quantitative Microscopy of Aristolochia indica Linn

\begin{tabular}{ccc}
\hline Parameters & Mean value & Range \\
\hline Stomata length $(\boldsymbol{\mu m})$ & 26.1 & $20.9-27.2$ \\
Stomata width $(\boldsymbol{\mu m})$ & 18.1 & $17.4-18.6$ \\
*Guard cell area GCA $\left(\boldsymbol{\mu m ^ { 2 }}\right)$ & 306.9 & $285.6-397.3$ \\
Stomatal density / $\mathbf{m m}^{2}$ & 121.0 & $20.3-138.6$ \\
Epidermal cell density / $\mathbf{m m}^{2}$ & 916.4 & $898.5-921.4$ \\
Stomatal index & 11.7 & $11.8-13.1$ \\
Vein-islet number $/ \mathbf{m m}^{2}$ & 5.0 & $3.9-5.2$ \\
Vein- termination $/ \mathbf{~ m m}^{2}$ & 7.2 & $6.1-9.9$ \\
Palisade ratio & 2.75 & $2.5-2.75$ \\
Size of areoles $(\mathbf{m m})$ & 0.08 & $0.07-0.09$ \\
\hline${ }^{*}$ Franco's formula.
\end{tabular}

${ }^{\star}$ Franco's formula.

Table 2: Physico-chemical parameters of the leaves of $A$. indica Linn

\begin{tabular}{cc}
\hline Parameters & Percentage w/w (Mean + SE) \\
\hline Total Ash & $12.72 \pm .004$ \\
Acid insoluble ash & $1.89 \pm .04$ \\
Acid soluble ash & $10.83 \pm .02$ \\
Water soluble ash & $1.92 \pm .002$ \\
Moisture & $10.5 \pm .02$ \\
Successive extractives & \\
Pet-ether & $4.19 \pm .02$ \\
Cyclohexane & $0.77 \pm .006$ \\
Acetone & $3.62 \pm .005$ \\
Ethanol & $6.51 \pm .01$ \\
\hline
\end{tabular}

Table 3: Qualitative phyto-chemical analysis of the leaves of $\boldsymbol{A}$.indica

\begin{tabular}{ccc}
\hline Type of compound & Reagents & Result \\
\hline Alkaloid & Ethanol extract +Dragon dorf's & + \\
Carbohydrate & Aqueous extract +Fehling A \& B & + \\
Phenolic compound & Ethanol extract + Neutral Ferric & + \\
chloride & + \\
Steroids & Ethanol extract + Distilled water & + \\
Thannin & Aqueous extract + Lead acetate & + \\
Protein & $\begin{array}{c}\text { Ethanol extract + con. Nitric acid } \\
\text { Ethanol extract + Benzene+ dil. }\end{array}$ & + \\
Glycosides & Ammonia & - \\
Flavanoid & Ethanol extract + con. HCL+ & - \\
& Magnesium ribbon+ boiling & absent - \\
\hline
\end{tabular}

as radiation source. The operating parameters for the working elements were set as recommended by the manufacturer. The optimization wizards within SOLAAR software (version 11.01) contains the pre-set spectrometer parameters for these metals were made the optimum analytical conditions and the plotting of calibration curve.

\section{Stock solution}

Stock solutions were containing $1000 \mathrm{ppm}$ of the elements such as; Cd, $\mathrm{Ni}, \mathrm{Zn}, \mathrm{Cu}, \mathrm{Pb}$ and Fe procured from Merck (Germany). Appropriate dilutions of these stock solutions gave the working standard of each element for plotting the calibration graph.

\section{Sample preparation}

Accurately weighed $2.422 \mathrm{~g}$ of shade-dried powdered drug was burnt to ashes in a muffle furnace by gradually increasing the temperature from $25^{\circ} \mathrm{C}$ to $450^{\circ} \mathrm{C}$, till the ashes turned to became white in color. The resulting ashes was digested in $24 \mathrm{ml}$ of solution containing $\mathrm{HCl}$ and $\mathrm{HNO} 3$ $(3: 1 \mathrm{v} / \mathrm{v})$ and digests were filtered and transferred to a standard volumetric flask and made up the volume as $100 \mathrm{ml}$ with de-ionized water. Analyses for metal elements in the sample were carried out in triplicate by flame Atomic Absorption Spectroscopy.

\section{Calibration curve}

The $1000 \mathrm{ppm}$ standard solutions of elements procured from Merck (Germany) were diluted in suitable four different working standard concentrations, and $2 \% \mathrm{w} / \mathrm{v} \mathrm{HNO} 3$ solution as blank, prepared immediately before the use. Calibration graph was plotted using the absorbance vs concentration of the standard solutions and the method of segmented fit was used for quantification of the elements in the leaves sample.

\section{RESULTS AND DISCUSSION}

\section{Macroscopic evaluation of Leaves}

The leaf of Aristolochia indica Linn is microphyll, which consisted of an average of $9.5 \mathrm{~cm}$ in length and $3.2 \mathrm{~cm}$. in width. The leaves were glabrous, very variable in size and green in color. Leaves were usually obovate-oblong, entire with undulate margins, cordate at the base, and having 3-nerved from base. When squeeze the fresh leaves produce a characteristic odor, and showed extreme bitter taste. Shade-dried leaves when pulverized to yield coarse power, and incinerated residue (ash) were appeared as white in color.

\section{Microscopic evaluation of Leaves}

Transverse sections (S.C) of the leaf showed dorsiventral differentiation. The midrib was broadly convex on the abaxial side and bluntly conical with short lump on the adaxial side (Figure 2). Midrib was consisted of three distinct tissue organizations such as the outer collenchyma, middle mesophyll, and inner vascular bundles. Collenchyma comprised of 6-7 layers. The vascular bundles appeared as crescent shaped and embedded in the middle of the ground tissues which were encircled by the sclerenchymatous bundle sheath. The mesophyll was consisted of the upper palisade tissues and lower spongy parenchyma (Figure 2a \& 2b). Palisade appeared as single layered, cells were cylindrical and top shaped. The mean height and breadth of the palisade cell was found to be $45.7 \mu \mathrm{m}$ (ranged 43.8-48.1 $\mu \mathrm{m}$ ) and $20 \mu \mathrm{m}$ (ranged 18.5-21.5 $\mu \mathrm{m}$ ) respectively, and the palisade ratio was found to be 2.7. The spongy mesophyll cells were elongated, lying parallel to the surface of lamina and occupied more than a half of the areas of the mesophyll tissues. The cells of the spongy mesophyll were round or rectangular, cells were loosely arranged with large intercellular spaces, and formed a lobed network of 4-5 layers. Both the palisade and spongy cells were contained with plenty of chloroplasts (Figure 2c). Xylem vessels were arranged in radial rows of 4 or 5 , and phloem lies on the abaxal side. The diameter of the vessel lumen ranged from $20 \mu \mathrm{m}$ to $34 \mu \mathrm{m}$. The midrib was appeared much broader and wider than the lamina. The lamina appeared flat and much reduced in dimension (Figure 2). Both epidermises were one cell thick, cells were compactly arranged and rectangular in shape having a prominent layer of cuticle over the outer cell wall. The thickness of the cuticle varies and found to be ranged from $6.2 \mu \mathrm{m}$ to $6.5 \mu \mathrm{m}$. The upper epidermal cells were larger in size (mean dimension $50.6 \mu \mathrm{m} \times 27.8 \mu \mathrm{m}$ ) compared to the lower epidermal cells (mean dimension $34.5 \mu \mathrm{m} \times 22.5 \mu \mathrm{m}$ ). The ground tissues of the lamina consisted of 3-4 layers of parenchymatous cells and cells were polygonal in shape.

\section{Trichomes}

The surface features of the epidermis showed non-glandular trichomes on both the adaxial and abaxial sides. Trichomes were uniseriate, having 
Table 4: Calibration data of Aristolochic acid I at 320nm by HPTLC method

\begin{tabular}{ccccccccc}
\hline Track & Vial & Rf & $\begin{array}{c}\text { Amount } \\
\text { Fraction }\end{array}$ & Height & X(calc) & Area & X(calc) & Remark \\
\hline 5 & 1 & 0.40 & $100.00 \mathrm{ng}$ & 87.54 & & 2125.75 & & Std 1 \\
6 & 1 & 0.41 & $200.00 \mathrm{ng}$ & 146.55 & 3861.64 & Std 2 \\
7 & 1 & 0.41 & $300.00 \mathrm{ng}$ & 195.45 & 5268.33 & & Std 3 \\
8 & 1 & 0.41 & $400.00 \mathrm{ng}$ & 235.15 & & 6533.41 & & Std 4 \\
12 & 2 & 0.42 & - & 97.11 & $0.00 \mathrm{ng}$ & 2551.12 & $99.88 \mathrm{ng}$ & Sample leaf \\
\hline
\end{tabular}

Table 5: Concentrations of metals in the shade-dried leaves of $A$. indica Linn

\begin{tabular}{ccc}
\hline Metal elements & $\begin{array}{c}\text { Reference levels } \\
\text { (mg/, }\end{array}$ & mg dry weight) \\
\hline Iron $(\mathbf{F e})^{36-37}$ & - & $544.20 \mathrm{mg} / \mathrm{kg}$ \\
Zinc $(\mathbf{Z n})^{36-37,40}$ & $40.00 \mathrm{mg} / \mathrm{kg}$ & $26.82 \mathrm{mg} / \mathrm{kg}$ \\
Copper $(\mathbf{C u})^{36-37,40}$ & $30.00 \mathrm{mg} / \mathrm{kg}$ & $2.20 \mathrm{mg} / \mathrm{kg}$ \\
Lead $(\mathbf{P b})^{39}$ & $1.0 \mathrm{mg} / \mathrm{kg}$ & $9.78 \mathrm{mg} / \mathrm{kg}$ \\
Nickel $(\mathrm{Ni})$ & - & $8.01 \mathrm{mg} / \mathrm{kg}$ \\
Cadmium $(\mathbf{C d})^{39}$ & $1.50 \mathrm{mg} / \mathrm{kg}$ & $1.62 \mathrm{mg} / \mathrm{kg}$ \\
\hline Source: ${ }^{39}$ &
\end{tabular}

Source: Joint Codex Alimentarius Commission ${ }^{36-39}$; Indian Standard ${ }^{40}$.

a short basal cell accompanied by an elongated terminal stalk cell (Figure $3 \mathrm{~b}$ ). In some of the trichomes, the terminal stalk cell appeared curved like a hook. Such hooked trichomes (Figure 3c) were found abundant on abaxial side of the lamina than the adaxial side. The outer epidermal layer of the mid rib was also provided with trichomes. The mean length of trichome was observed as $46.08 \mu \mathrm{m}$. The mean diameter of the bulbous basal cell of the trichome was found to be of $14.14 \mu \mathrm{m}$ and that of terminal cell was $6.18 \mu \mathrm{m}$.

\section{Epidermal characters}

Epidermes showed the amphistomatic and anomocytic stomata (Figure $3 \& 3 a$ ). The density of the stomata was found to be at variance in both epidermses. The stomata were observed much higher in number on the abaxial epidermis than adaxial epidermis. Pataky ${ }^{31}$ had classified the stomata with guard cell having measured a length of more than 38 $\mu \mathrm{m}$ as "large" and however, in the present study the mean length and breadth of stomata was found to be $26.1 \mu \mathrm{m}$ and $18.1 \mu \mathrm{m}$ respectively. According to Meltcafe and Chalk ${ }^{26}$ the taxon having small sized stomata usually gave the high stomatal density, and their findings did hold true for A. indica Linn which gave a high mean stomatal density of 121 per square millimeter areas for the abaxial surface of the leaf. The stomatal index of $A$.indica Linn was found to be $11.7 / \mathrm{mm}^{2}$, and the mean Guard cell area (GCA) was of $306.9 \mu \mathrm{m}^{2}$ Meltcafe and Chalk ${ }^{26}$ have reported that the stomatal index could be used as a reliable taxonomic character for identifying the species, as the epidermal cell size is independent of the changes brought about by environmental factors. The epidermal cells were straight or wavy in nature, and the number of epidermal cells per square millimeter area of the leaf was found to be 916.4 (Table 1). The mean pore aperture length and breadth of the guard cell of A.indica was found to be $7.38 \mu \mathrm{m}$ and $2.45 \mu \mathrm{m}$ respectively.

\section{Petiole}

In cross sectional view the petiole was appeared somewhat spherical in shape with a deeply notched groove at the adaxial side (Figure 4). Epidermis was consisted of singled layered, elongated and rectangular shaped cells. Beneath the upper epidermis laid 3-4 layered collenchymatous hypodermis. The petiolar bundles were five in number and found to be arranged in the form of letter " $v$ ". The median three bundles were larger in size compared to the two laterals. The vascular bundles were widely separated from one another by parenchymatous ground tissues. Vascular bundles were collateral; the xylem vessels were arranged in radial rows of 3-4, and phloem situated in the abaxial side. The lumen of xylem vessels varied in size; its diameter ranged from $18 \mu \mathrm{m}$ to $24 \mu \mathrm{m}$. Cells of the parenchymatous ground tissue had often contained the prismatic crystals of calcium oxalate.

\section{Venation Pattern}

The leaf architectural characters could also provide useful anatomical information for the characterization of the taxon. The terminology used for description of the leaf architecture in the present study was as per the Hickey. ${ }^{27}$ The venation patterns of cleared leaves of Aristolochia indica Linn had observed the camptodromous pinnate venation under low $(\times 2)$ magnification. Areolation was found to be well developed and pentagonal or polygonal in shape. The size of the areoles was small $(>0.30 \mathrm{~mm})$. When critically analyzed microscopically, the number of areoles/ $\mathrm{mm}^{2}$ was found to be 13.3. Within the areoles the terminal vein-ending was observed and the number of vein-endings per areola was found to be one, and appeared as linear (Figure 5). Veinlets of the lamina were observed twice branched and the marginal veins appeared fimbriate (Figure 5a). The minor venation pattern viz. the mean vein islet number/ $\mathrm{mm}^{2}$ of leaf was found to be 5 , and the veinlets termination number $/ \mathrm{mm}^{2}$ were 7.2. The mean size of the areole was found $0.08 \mathrm{~mm}$.

\section{Powder microscopy}

Powdered drug under the microscope showed the presence of fragments of leaf epidermis with cell having straight wall and the cells appeared pentagonal or hexagonal in shape, and lamina comprised of having conspicuous venation (Figure $6 \& 6 a$ ).

\section{Fluorescence Analysis}

Fluorescence analysis could be very useful adjunct to the botanical study, since it is an easy test to verify certain identification parametes of the crude drug. Hence, dried powdered leaves were taken in a series of solvent systems with increasing polarity as follows; petroleum ether, cyclohexane, toluene, benzene, ethylacetate, chloroform, acetone, ethyl alcohol and methanol. Their fluorescence properties were analyzed under the dual UV light ( $254 \mathrm{~nm}$ and $366 \mathrm{~nm}$ ). Under the short wavelength $(254 \mathrm{~nm})$, leaves extracts in all the solvent systems were found to be nonflorescent, whereas they observed florescent at $366 \mathrm{~nm}$. All the extracts were appeared pink to orange color at $366 \mathrm{~nm}$; except the extract of Toluene, where it appeared as cream white. The aqueous extract of the leaves was also found to be appeared as cream white. The leaf- powder in day light appeared green in color, and was highly bitter in taste.

\section{Physico-chemical Evaluation}

The evaluation of the physico-chemical constants of the drug is an important parameter for detecting the adulteration or improper handling of the drug. The values of the extractive yield of the drug obtained in a series of solvents were depicted in Table 2 . The Table 2 showed that the percentage extractive yield obtained for ethanol was found to be higher 


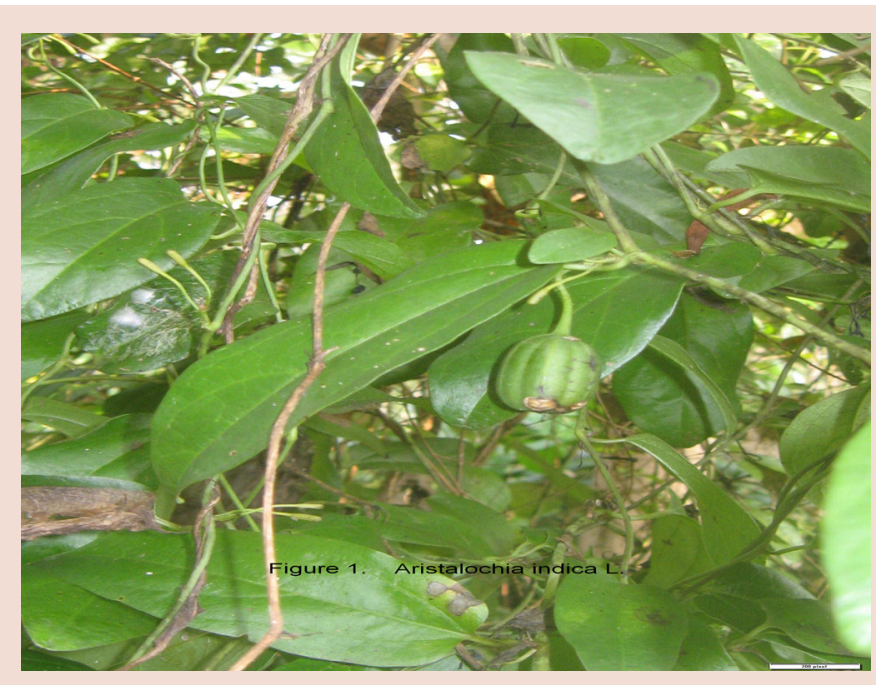

Figure 1: Aristolochia indica $\mathrm{L}$.

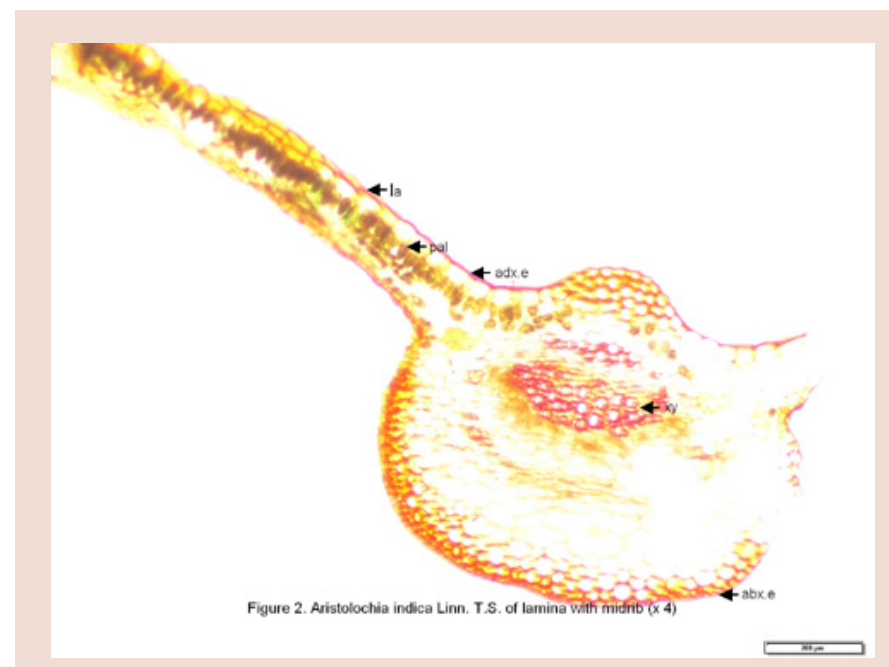

Figure 2: T.S. of Lamina with midrib(x 4)

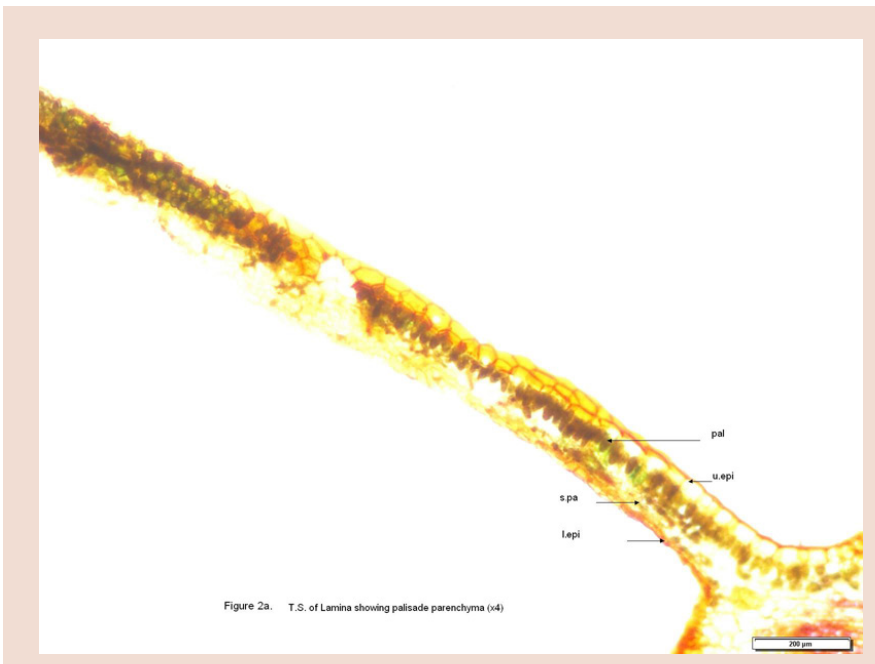

Figure 2a:T.S. of Lamina showing palisade (x 4)

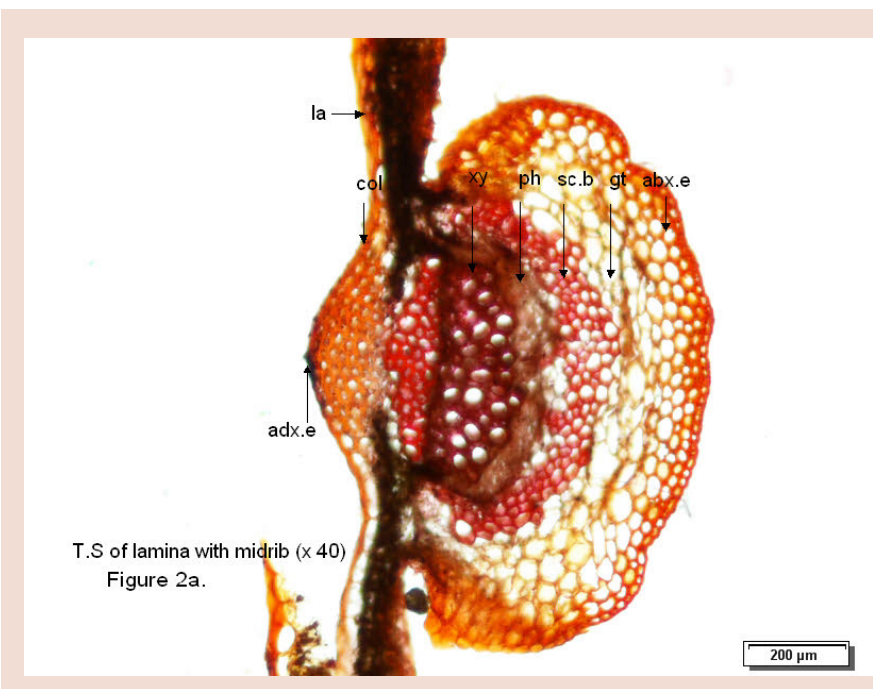

Figure 2b:T.S. of Lamina with midrib(x 40)

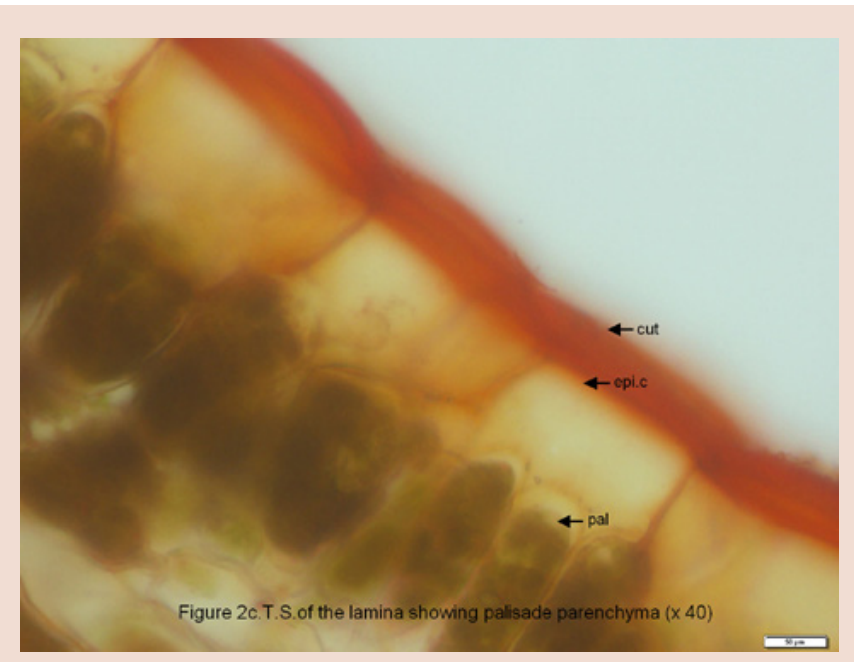

Figure 2c: T.S. of Lamina showing palisade (x 40)

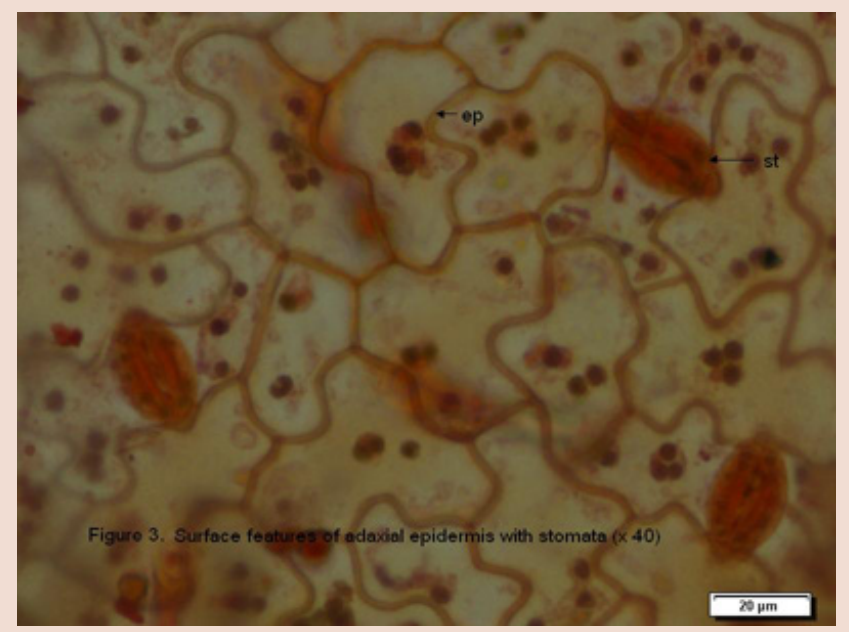

Figure 3: Surface features of adaxial epidermis with stomata( $x 40)$ 


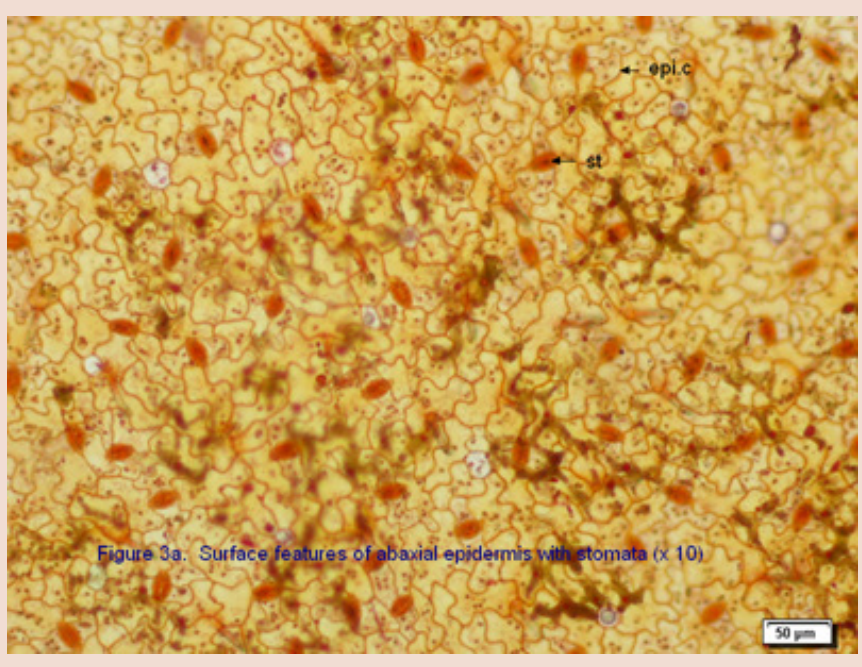

Figure 3a: Surface features of abaxial epidermis with stomata (x 10)

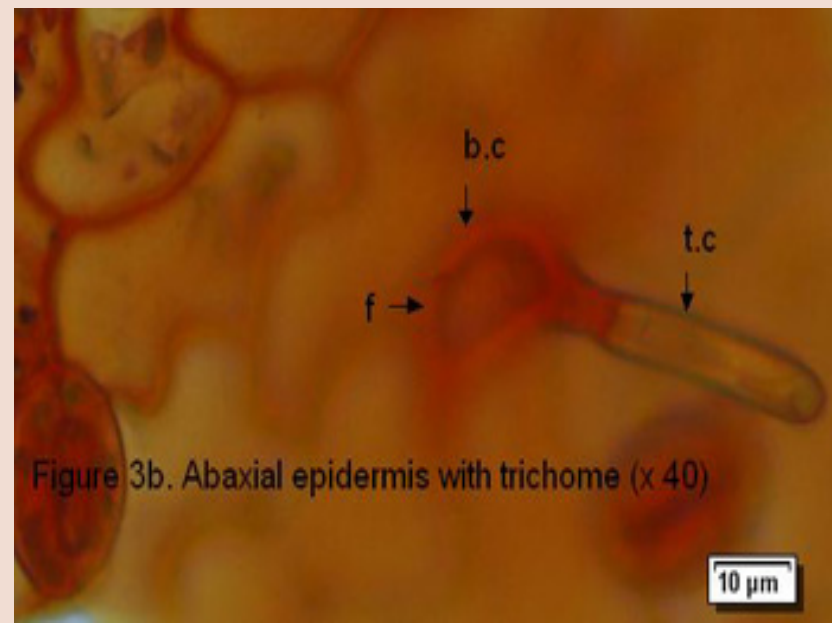

Figure 3b: Abaxial epidermis with trichome $(x 40)$

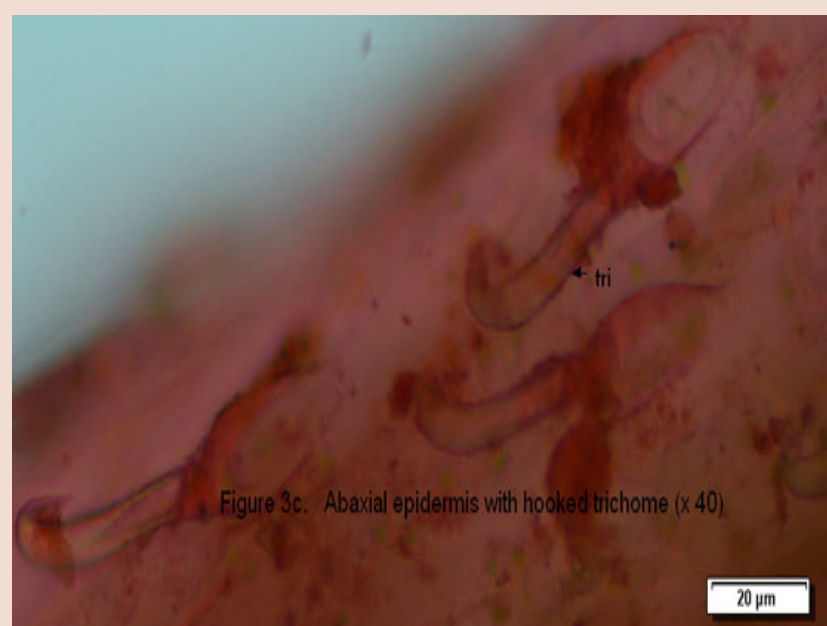

Figure 3c: Abaxial epidermis with hooked trichome $(x 40)$

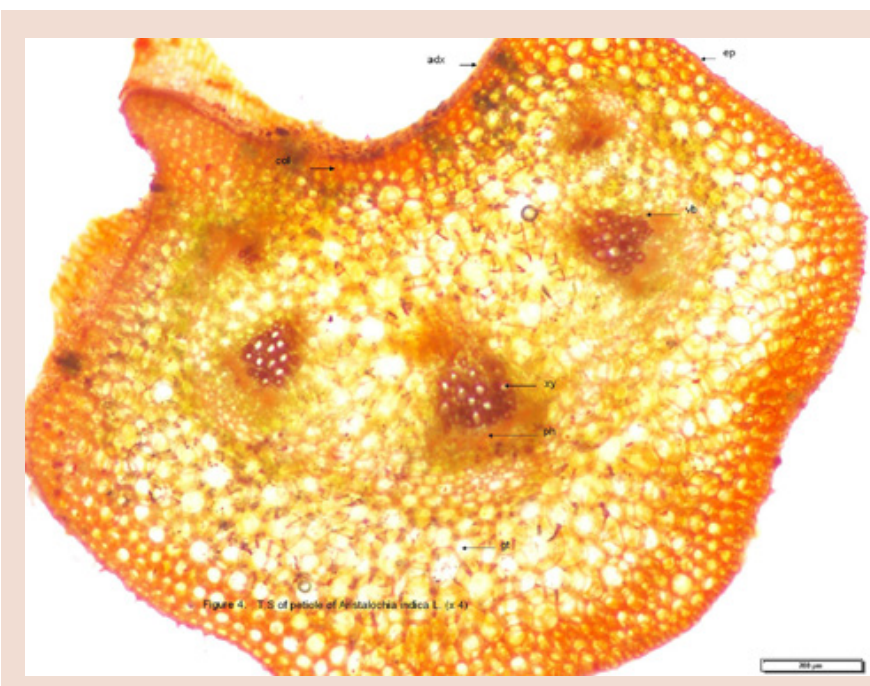

Figure 4: T.S of Petiole of Aristolochia indica L. (x 40)

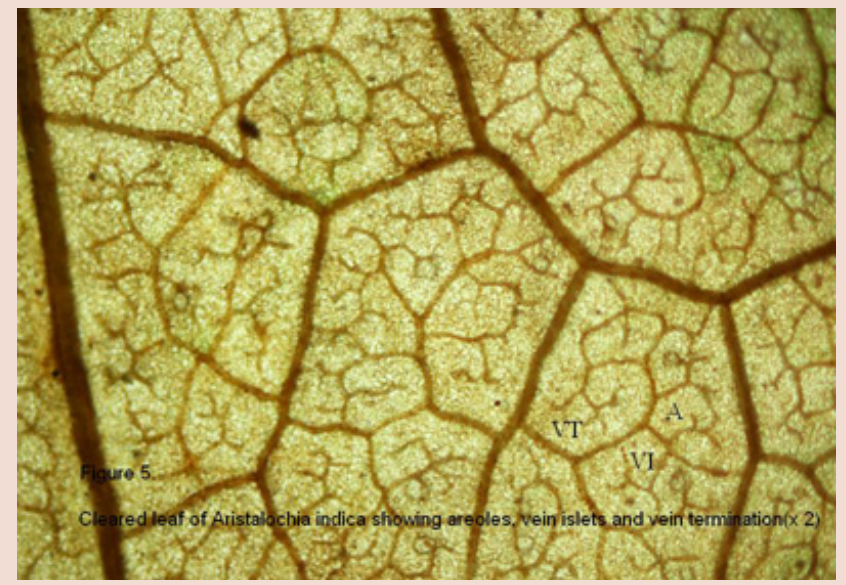

Figure 5: Cleared leaf of Aristolochia indica showing areoles, vein-islets and vein termination $(x 2)$

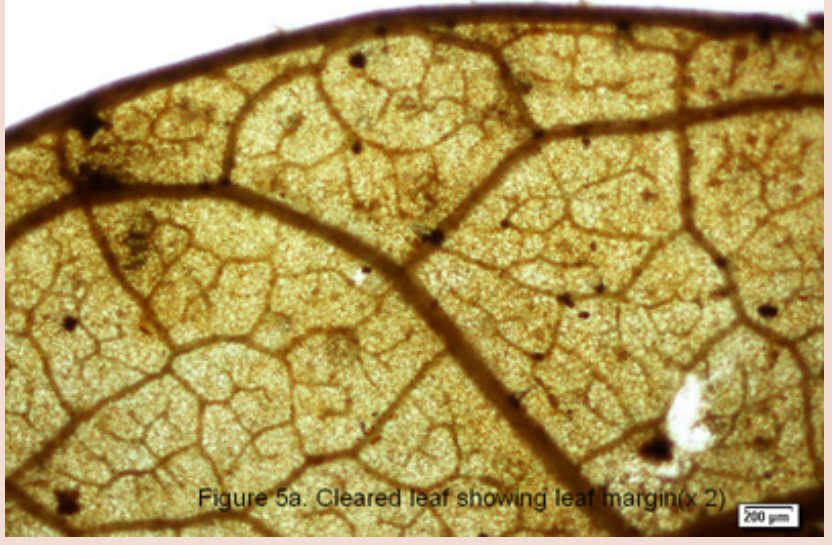

Figure 5a: Cleared leaf showing leaf margin (x 2) 


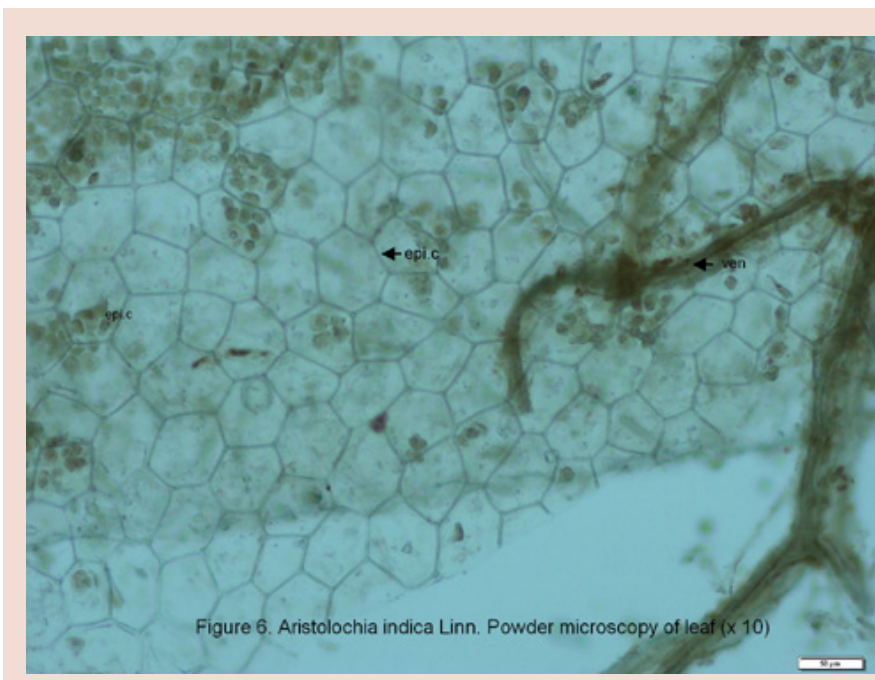

Figure 6: Powder microscopy of leaf (x 10)

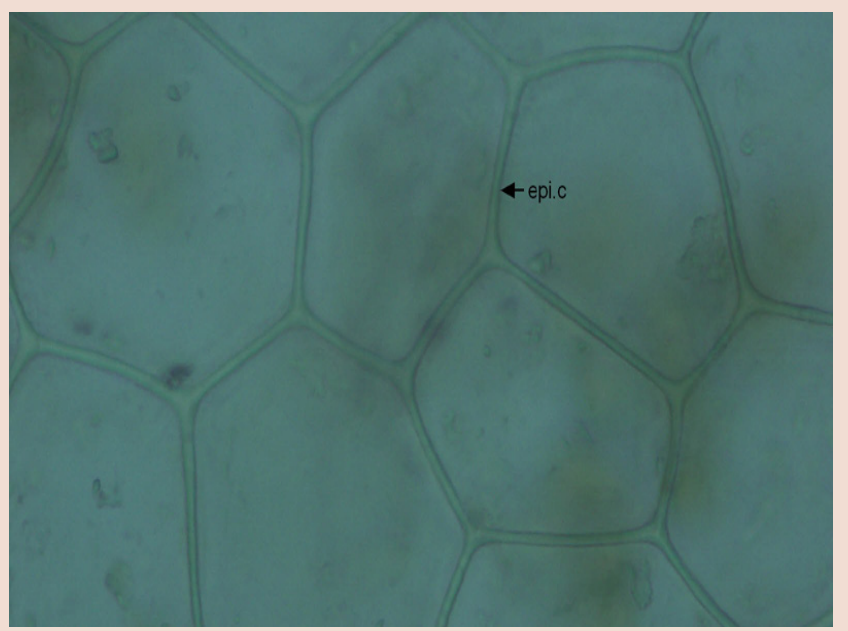

Figure 6a: Powder microscopy of leaf $(x 40)$

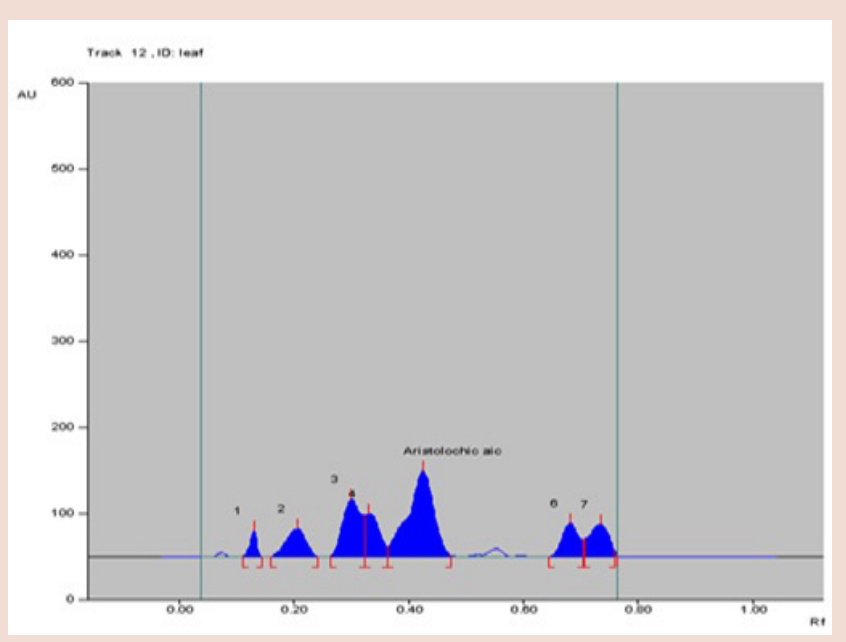

Figure 7: HPTLC profile of methanol extract of the leaf of Aritolochia indica

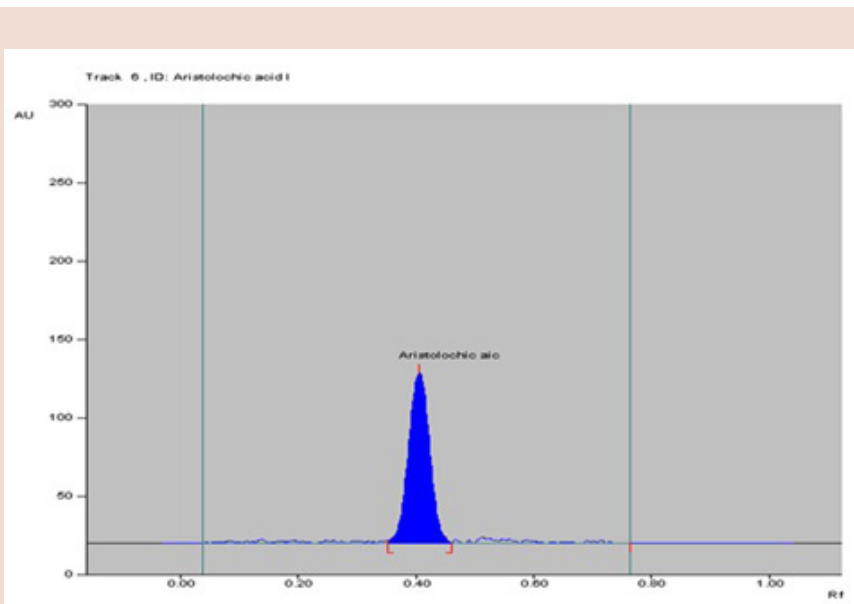

Figure 8: HPTLC chromatogram of Aristolochic acid I ( $200 \mathrm{ng} / \mathrm{band}$ ) with $R_{f}=0.41$

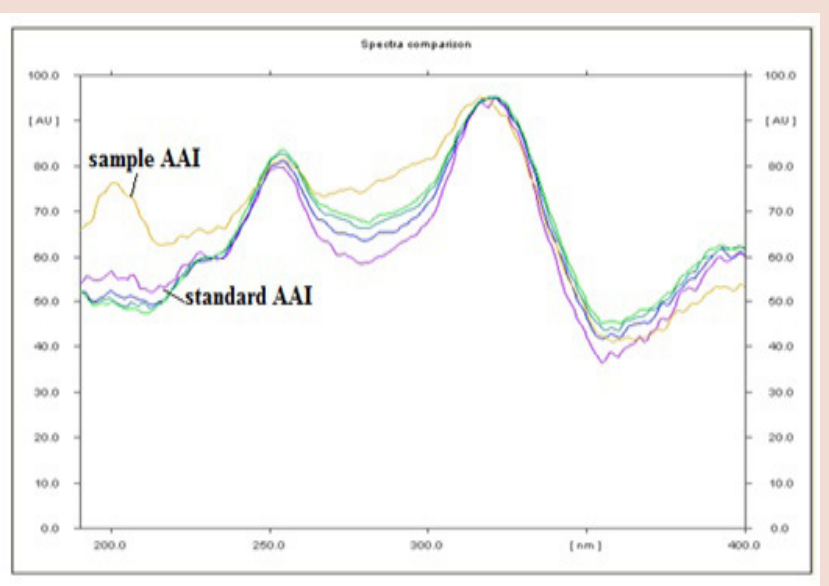

Figure 9: Overlay of spectra $\left(\lambda_{\max } 318 \mathrm{~nm}\right)$ with standard AAI and methanol extract of leaves

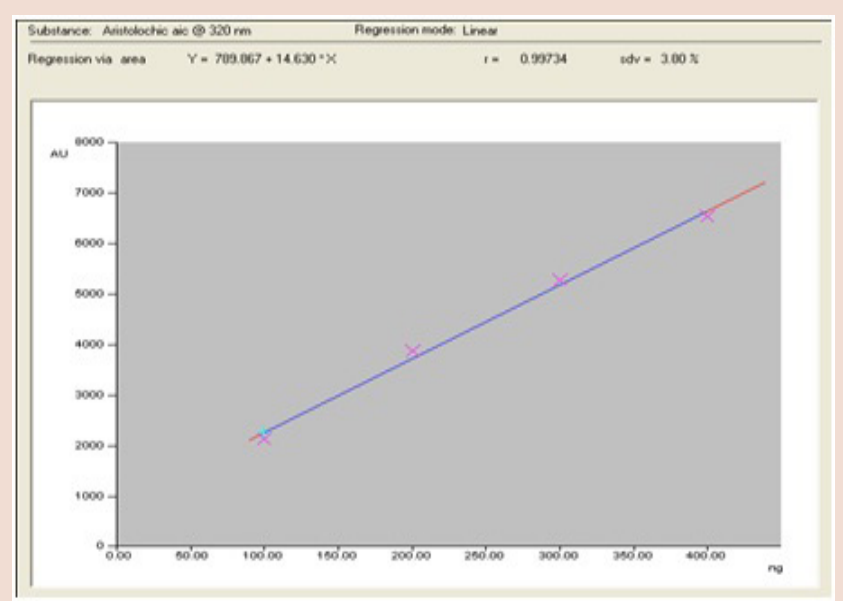

Figure 10: Calibration curve of Aristolochic acid I (concentration Vs peak area) 
and relatively low value obtained for Cyclohexane. The moisture content of the shade-dried powdered drug was found be not more than $10.5 \%$, which often discourages the growth of microbes. The total residual ash value was found to be higher than that of the acid soluble ash. The value of $1.89 \%$ obtained for the acid insoluble ash in the present study may be owing to the incidence of siliceous matters in the crude drug.

\section{Qualitative phyto-chemical analysis}

The preliminary screening of the methanol leaves extract of Aristolochia india Linn had showed the presence of alkaloid, carbohydrate, phenols, steroid and saponin and the results obtained were depicted in Table 3.

\section{HPTLC Finger print}

The spotted samples of methanol extract of leaves and standard marker compound (AAI) containing on the silica gel plates were developed in the Automatic development chamber (ADC2) with the solvent system Chloroform: Ethanol 22.5:7.5 (v/v) to a distance of $8 \mathrm{~cm}$. All tracks in the plate were scanned at $254 \mathrm{~nm}$ and individual $\mathrm{Rf}$ values and the resolved bands were recorded. Chromatogram of the drug extracted from the leaves had revealed 9 phyto-constituents. Data of peak area, peak height, $\mathrm{Rf}$ value of each band were recorded in track no.12 and the expressed pattern of chemical ingredient's distribution were also depicted in Figure 7. Out of these bands, one band $\left(\mathrm{R}_{\mathrm{f}}=0.42\right)$ generated matched with the $R_{f}$ value $\left(R_{f}=0.41\right)$ of the marker compound (Figure 8$)$ and the densitometric scanning had the same $\lambda_{\max }(318 \mathrm{~nm})$ as that shown by Standard Aristolochic Acid I.

\section{Quantitative Estimation}

Quantitative investigation of the marker compound (AAI) was carried out by densitometric reflection/absorption mode at $320 \mathrm{~nm}$ (Figure 9). Spectral matching by overlaying the absorption spectra of standard marker compound (100-400 ng/band) with the absorption spectrum of marker compound in leaves sample (ie., AAI in the leaves-sample) was confirmed the specificity of $\boldsymbol{\lambda}_{\max }$ at $318 \mathrm{~nm}$ (Figure 9).

\section{Calibration curve}

When the concentrations of Aristolochic Acid I $\left(\mathrm{C}_{17} \mathrm{H}_{11} \mathrm{NO}_{7}\right)$ and their respective peak areas were subjected to regression analysis by least squares method, calibration curve was found to be linear in the concentration range of 100 to $400 \mathrm{ng} / \mathrm{b}$ and with the calibration equation $\mathrm{Y}=789.867+14.63 \mathrm{X}$ and regression coefficient, $\mathrm{r}=0.997$ and $\mathrm{sdv}=3.8 \%$ (Figure 10). Calibration graph showing the acceptable correlation $(\mathrm{r}=0.99)$ between the marker compound in both the methanol extract of leaves and standard in the track had revealed a good linearity response for the method developed (Figure 10). The calibration data depicted in Table 4 had revealed that $5 \mu \mathrm{L}$ of methanol extract of leaves contained $99.88 \mathrm{ng}$ of Aristolochic acid I and the content of marker constituent (AA I) present in dried leaves sample of Aristochia india Linn (a Kerala habitant) was estimated as $0.049 \%$.

A validated HPTLC method for the quantification of the Aristolochic acid I present in the dried root samples of Aristolochia indica Linn had already been developed by this author ${ }^{23}$ and results obtained suggests that the concentration of bioactive compound (AAI) is very high in the shade-dried roots $(0.08 \%)^{23}$ when compared to that of the shadedried leaves $(0.049 \%)$. However, the study fails to obtain any detectable amount of Aristolochic acid I from the dried stem of Aristolochia india Linn by HPTLC method, which further justifies the privileged use of its roots and leaves for the preparations of Indian traditional herbal medicine.

\section{Sensitivity of the HPTLC method}

The sensitivity of an instrument is a measure of its ability to discriminate between small differences in analyte concentrations in an analytical procedure. According to Srivastava ${ }^{32}$ a signal-to-noise ratio $(\mathrm{S} / \mathrm{N})$ of 3 and 10 were generally be considered as limits of detection (LOD) and limits of quantitation (LOQ) respectively for HPTLC. The LOD and LOQ values of AAI calculated from the calibration regression equation were found to be $0.779 \mathrm{ng}$ and $2.597 \mathrm{ng}$ respectively. This suggests that the developed HPTLC method exhibits a good sensitivity for the quantitation of AAI. The developed active constituent based on HPTLC method has the advantage of simple, specific and easy identification of Aristolochic acid I in the leaves samples and could be applied for the regulatory perspective as routine quality analysis for the Aristolochia species in the formulation/finished products.

\section{Flame Atomic Absorption Spectroscopic evaluation of metal elements}

Analyses of the flame atomic absorption spectrometry after acid digestion of the leaves extract showed the mean concentrations of metals in the leaf-sample were in the order of $\mathrm{Fe}(544.2 \pm 0.02)>\mathrm{Zn}(26.82 \pm$ $0.004)>\mathrm{Pb}(9.78 \pm 0.005)>\mathrm{Ni}(8.01 \pm 0.005)>\mathrm{Cu}(2.2 \pm 0.002)>\mathrm{Cd}(1.62 \pm$ 0.001 ). The results showed that (Table 5), iron had the highest concentration in the investigated samples followed by zinc and the least encountered were cadmium.

Since, the dietary intakes of fruits, vegetables and crude drugs are known the most affordable source of minerals and vitamins important to the human health. Exceeding the maximum tolerable levels or the excessive uptake of dietary heavy metals may cause serious health problems, owing to their long biological half-lives, non-biodegradable nature and their potential to accumulate in most systemic parts of the body. ${ }^{33-4}$ Therefore, many standards and a great deal of recommendations exist all over the world regarding the amount of heavy metals tolerable levels for the animals and humans, including the limit for the level of heavy metals concentration in different plant types such as vegetables, cereal crops and medicinal plants. ${ }^{35}$ The standard values set out by the Codex Alimentarius Commission $(\mathrm{FAO} / \mathrm{WHO})^{36}$ for the daily intakes for $\mathrm{Fe}$ is $0.767 \mathrm{mg} / \mathrm{kg} /$ day for both children and adults. The international standard limits for $\mathrm{Pb}, \mathrm{Cd}$, $\mathrm{Cr}$, and $\mathrm{Cu}$ for an average person (70 kg body weight); for daily intakes through the consumption of root vegetables are limited to $250 \mu \mathrm{g}, 70 \mu \mathrm{g}$, 50-200 $\mu$ g and $35 \mathrm{mg}$ respectively. ${ }^{37-9}$ In Prevention of Food Adulteration Acts \& Rules of India, ${ }^{40}$ the permitted limits for $\mathrm{Cu}, \mathrm{Zn}, \mathrm{Pb}$ and $\mathrm{Cd}$ levels for the fruits and vegetables are found to be 30,50, 1 and 1.5 parts per million by weight respectively. Ajasa et al., ${ }^{41}$ have reported that micronutrient elements $\mathrm{Cu}$ and $\mathrm{Zn}$ in agricultural products may be ranged between level $4-15 \mathrm{mg} / \mathrm{L}$ and $15-20 \mathrm{mg} / \mathrm{L}$ respectively and concentration of iron may be ranged between $261 \mathrm{ppm}$ to $1230 \mathrm{ppm}$ for some medicinal plants. The $\mathrm{WHO}^{42}$ prescribed limit for lead contents in herbal medicine is $10 \mathrm{ppm}$ while the dietary intake limit for lead is $3 \mathrm{mg} /$ week. However, for medicinal plants the WHO limits yet to be established for $\mathrm{Fe}$ and $\mathrm{Ni}$.

The estimated values for the mineral elements in shade-dried leaves of A. indica Linn (Table 4) in the present study suggests that the use of this plant's leaves in moderate quantities would provide the range of amounts of $\mathrm{Fe}, \mathrm{Zn}, \mathrm{Cu}$ and $\mathrm{Ni}$ necessary for the healthy body. The presence of some important mineral elements inside this plant also showed that it could be a nutritious plant and important to the human health. However, the high concentration of toxic element $\mathrm{Pb}$ in the leaves may pose risk to human health and hence be cautious for the indiscriminate use of the leaves. 


\section{CONCLUSION}

The present study suggests that the delineated characteristics of the leaves of $A$. indica, could tag as the identifying parameters to substantiate and authenticate the raw drugs from the spurious/adulterants materials and which could also be effectively used for the regulatory perspectives and quality assessment of Aristololic acid I (AAI) in the medicinal formulation/finished products. The presence of important mineral elements inside this plant showed that it could be a nutritious plant and important to the human health.

\section{ACKNOWLEDGEMENT}

The author is thankful to Dr. PK Ashok, Principal, Government Ayurveda College, Thiruvananthapuram for providing the facilities for carrying out this work.

\section{CONFLICT OF INTEREST}

Author has declared that no conflict of interest exists

\section{Abbreviations used in the figures are}

A: Areola; Abx: Abaxial; Abx.E: Abaxial Epidermis; Adx: Adaxial, Adax.E: Adaxial Epidermis; B.C: Basal Cell; Col: Collenchyma; Crl : Crystal; Cut: Cuticle; Ep, Epi.C: Epidermal Cell; Epi: Epidermis; F: Foot Cell; Gu.C: Guard Cell; Gt: Ground Tissue; La: Lamina; L. Up: Lower Epidermis; Pal: Palisade Cell; Ph: Phloem; Pi: Pith; Scb: Sclerenchymatous Bundle Sheath; Spa,Spo: Spongy Parenchyma; St: Stomata; Stcl: Stone Cell; Str: Starch Grain; S.Xy: Secondary Xylem; Tri: Trichome; T.C: Stalk Cell; U.Epi: Upper Epidermis; Vb: Vascular Bundle; VI: Vein Islet; VT: Veinlet Termination.

\section{REFERENCES}

1. Kuo P, LiY, and WuT. Chemical Constituents and Pharmacology of the Aristolochia Species. J Tradit Complement Med. 2012;2(4):249-66.

2. Che CT, Cordell GA, Fong HHS, Evans CA. Studies on Aristolochia. Part 2. Aristolindiquinone - A new naphthoquinone from Aristolochia indica L.(Aristolochiaceae). Tetrahedron Lett.1983;24(13):1333-36.

3. Grolliman AP, Scarborough J, Jelakovic B. Aristolochic acid nephropathy: An environmental and laterogenic disease. In: A Fishbien JC, editor. Advances in Molecular Toxicology. New York: Elsevier. 2009;3:211-27.

4. Duke JB. Handbook of Medicinal herbs. $2^{\text {rd }}$ Ed. CRS Press: Boca Raton; p.294;2002.

5. Lopes LMX, Nascimento IR, Silva DT. Phytochemistry of the Aristolochiaceae family, in Research advances in phytochemistry. 2001;2:19-108.

6. Bensky D, Clavey S, Stöger E, Gamble A, Bensky LL.Chinese Herbal Medicine: Materia Medica $3^{\text {rd }}$ Ed. Seattle: Eastland Press; p.412; 2003.

7. Pharmacopeia of China. Vol. 1. Beijing:Peoples Press; 1985.

8. Perry LM. Medicinal Plants of the East and Southeast Asia.Cambridge: MIT press; 1980

9. WuTS, Damu AG, Su CR, Kuo PC. Terpenoids of Aristolochia and their biological activities Review. Nat Pro Rep. 2004;21(5):574-624

10. Martinez M. Las Plantas Medicinales de Mexico. $6^{\text {th }}$ ed. Botas: D.F.Mexico; 1991.

11. Chopra RN, Nayar SL, Chopra IC. Glossary of Indian medicinal plants. Council of Scientific \& Industrial Research; New Delhi; p.67;1956.

12. Vagbhata's Astanga Hrdayam, Text, English Translation, Notes, Appendix and Indices. Vol III. (Uttara Sthana). Murthy KRS, Translator. Varanasi India: Chowkhamba Sanskrit Series Office; 2002.

13. Jiménez-Ferrer JE, Pérez-Terán YY, Román-Ramos R, Tortoriello J. Antitoxin activity of plants used in Mexican traditional medicine against scorpion poisoning. Phytomedicine. 2005;12:116-22.
14. Achari BS, Chakrabarty, SC, Pakrashi A. An N-glycoside and steroids from Aristolochia Indica. Phytochemistry. 1985;20(6):1444-45.

15. Nortier JL, Martinez MM, Schmeiser HH, Arlt VM, Bieler CA, Petein M, et al. Urothelial Carcinoma Associated with the use of a Chinese Herb (Aristolochia fang(hi). N Engl J Med. 2000;342(23):1686-92.

16. U.S. FDA. Letter to health care professionals FDA concerned about botanical products, including dietary supplements, containing Aristolochic acid. 2002 Dec [cited 2002 Dec 23].

17. Dey A, Nath DJ. Aristolochia indica L: A Review. Asian J Plant Sci. 2011;10(2): 108-16.

18. Rajashekaran S, Pushpangadan P, Kumar PKR, Jawahar CR, Nair CPR, Amma LS Ethono-medico-botanical studies of cheriya arayan and valiya arayan (Aristalochia indica Linn: Aristalochia tagala Cham.).Ancient Sci Life.1989;9(2): 99-106.

19. Philip T. Foliar stomatal development in 3 species of Aristolochia. Curr Sci. 1989; 52: 223-24.

20. Bal SN, Gupta B. Morphology of roots of Aristolochia indica Linn. Sci Cult. 1956; 22: $276-77$.

21. Iyer NK, Kolammal M. Aristalochia indica Linn.in Pharmacognosy of Ayurvedic Drugs, Kerala. Series 1, No.6: (Pagination missing) Thiruvananthapuram: Pharmacognosy Unit, Government Ayurveda College;1994.

22. Indian Council of Medical Research; Aristalochia indica Linn. Qualitative standards of Indian Medicinal plants, Vol 2. New-Delhi: Indian council of Medical Research; 2005.

23. Sudhakaran, MV. Pharmacognostic and HPTLC Fingerprint Profile of the Root of Aristolochia indica Linn and Quantification of the Marker Compound. European J Med Plants. 2014;4(9):1113-24.

24. Gamble JS. Flora of the presidency of Madras. Dehra Dun:Bishen Singh Mahendra PalSingh; 1984.

25. Wallis TE. A text book of Pharmacognosy. $3^{\text {rd }}$ ed. London: J \& A Churchill; 1976

26. Franco CM. Relationship between chromosome number and stomata in Coffee. Bot Gaz. 1939;100(4):817-27.

27. Hickey LJ. Classification of the Architecture of Dicotyledeneous Leaves. Am J Bot.1973;60(1):17-33

28. Sudhakaran MV. Botanical pharmacognosy of Andrographis paniculata (Burm. F.) Wall. Ex. Nees. Phcog J.2012;32(4):1-10.

29. Sudhakaran MV. Histo-morphological, fluorescent and powder microscopic characterization of Cissampelos pareira Linn. Phcog J.2012;34(4):57-68.

30. Ministry of Health and Family Welfare, Government of India; The Ayurvedic Pharmacopoeia of India. Vol 3. Part-I. $1^{\text {st }}$ ed. New Delhi; 2001.

31. Pataky S. Leaf epidermis of Salix, in Anatomy of the Dicotyledons. Vol 1. $2^{\text {nd }}$ ed. CR, Metcalfe and L. Chalk. Great Britain:The Clarendon, Oxford; 1969.

32. Srivastava MM. High performance thin layer chromatography. MM Srivastava, ed. London:Springer-Verlag, Berlin Heidelberg; 2011.

33. Jarup L. Hazards of heavy metal contamination. Br Med Bull. 2003;68(1):16782.

34. Turkdogan MK, Kilicel F, Kara K, Tuncer I, Uygan I. Heavy metals in soil, vegetables, and fruits in the endemic upper gastrointestinal cancer regions of Turkey. Environ Toxicol Pharm. 2002;13:75-79.

35. Aliyu AB, Musa AM, Oshanimi JA, Ibrahim HA, and Oyewale AO. Phytochemical analyses and mineral elements composition of some medicinal plants of Northern Nigeria. Nigerian J Pharm Sci. 2008;7(1):119-25.

36. Codex Alimentarius Commission (FAOMHO). Food additives and contaminants, (ALINORM 01/12A:1-289). Joint FAONHO Food Standards Program; 2001.

37. Food and Agriculture Organization of the United Nations (FAONHO) Summary and conclusions performed by Joint FAONHO Expert Committee on Food Additives. 50 $0^{\text {th }}$ Meeting; 1999 June 15-19; Rome: Food and Agriculture Organization of the United Nations; 1999.

38. FAOMHO. Inventory of substances used as processing AIDS (IPA), updated list performed by joint FAONHO food standards programme codex committee on food additives. In 42 ${ }^{\text {nd }}$ Session; 2010 March; Beijing: Food and Agriculture Organization of the United Nations; 2010.

39. National Research Council. Recommended dietary allowances, $10^{\text {th }}$ ed. Nationa Research Council. Washington, DC: Academic Press; 1989.

40. Prevention of Food Adulteration Acts \& Rules (Amended upto 1.10. 2004). Part XI Rule 57. Poisonous metals.

41. Ajasa AMO, Bell MO, Ibrahim AO, Ogunwande IA, Olawore NO. Heavy trace metals and micronutrients status in herbal plants of Nigeria. Food Chemistry. 2004;85(1):67-71.

42. World Health Organisation. Quality Control Methods for Medicinal Plant Materials. Geneva:WHO; 2005. 
PICTORIAL ABSTRACT

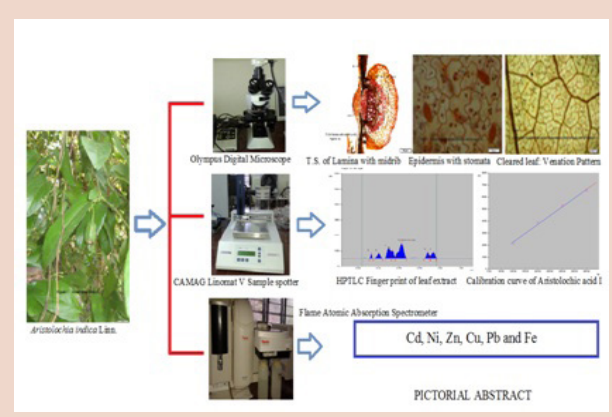

\section{SUMMARY}

- Aristolochic acid I (AAI) is the most potent fraction of Aristolochia's constituents, and the members of this genus have been used for medicinal purposes since the Graeco-Roman period, and the root and leaves of Aristolochia species were found used in Indian System of medicine.

- High-performance thin-layer chromatographic (HPTLC) method developed had revealed nine phyto-constituents in methanol extract of leaves and the content of marker compound, AAI was found to be $0.049 \%$ by dry weight of the leaves.

- The Flame atomic absorption spectrometric determination of elements had shown appreciable amounts of the elements such as $\mathrm{Fe}, \mathrm{Zn}, \mathrm{Ni}$ and $\mathrm{Cu}$.

- The leaf anatomical markers, quantitative microscopy, chemoprofiling and HPTLC profile of Aristolochia india delineated in this study could effectively be used for the regulatory perspectives of the quality assessment of the raw drugs and the medicinal formulation/finished products.

\section{ABOUT AUTHORS}

Madathilparambil Vasu Sudhakaran (M.V.Sudhakaran): Has received the Ph.D Degree of the University of Kerala. Currently he is positioned as Associate Professor, UGC-Academic Staff College of the University of Calicut. He is a research guide in Botany under the faculty of Science. His research interests include genetic diversity analysis, genetic effects of inbreeding, and the pharmacognostical and phytochemical aspects of medicinal plants. 